OPEN ACCESS

Edited by:

Marilia Seelaender,

University of São Paulo, Brazil

Reviewed by:

Sharon Ross,

National Cancer Institute (NCl),

United States

Purna Mukherjee

Boston College, United States

*Correspondence:

Laurent Hiffler

laurenthiffler@gmail.com

Specialty section:

This article was submitted to

Clinical Nutrition,

a section of the journa

Frontiers in Nutrition

Received: 23 May 2020

Accepted: 10 August 2020

Published: 04 September 2020

Citation:

Hiffler L and Rakotoambinina B (2020) Selenium and RNA Virus Interactions:

Potential Implications for SARS-CoV-2

Infection (COVID-19).

Front. Nutr. 7:164

doi: 10.3389/fnut.2020.00164

\section{Selenium and RNA Virus Interactions: Potential Implications for SARS-CoV-2 Infection (COVID-19)}

\author{
Laurent Hiffler $^{1 *}$ and Benjamin Rakotoambinina ${ }^{2}$ \\ ${ }^{1}$ Independent researcher, Lagny-sur-Marne, France, ${ }^{2}$ LRI Isotopic Medicine Lab, University of Antananarivo, Antananarivo, \\ Madagascar
}

SARS-CoV-2 is an RNA virus responsible for the COVID-19 pandemic that already claimed more than 340,000 lives worldwide as of May 23, 2020, the majority of which are elderly. Selenium (Se), a natural trace element, has a key and complex role in the immune system. It is well-documented that Se deficiency is associated with higher susceptibility to RNA viral infections and more severe disease outcome. In this article, we firstly present evidence on how Se deficiency promotes mutations, replication and virulence of RNA viruses. Next, we review how Se might be beneficial via restoration of host antioxidant capacity, reduction of apoptosis and endothelial cell damages as well as platelet aggregation. It also appears that low Se status is a common finding in conditions considered at risk of severe COVID-19, especially in the elderly. Finally, we present a rationale for Se use at different stages of COVID-19. Se has been overlooked but may have a significant place in COVID-19 spectrum management, particularly in vulnerable elderly, and might represent a game changer in the global response to COVID-19.

Keywords: selenium, COVID-19, SARS-CoV-2, thioredoxin reductase, RNA virus, elderly, obesity, oxidative stress

\section{INTRODUCTION}

SARS-CoV-2 is responsible for the COVID-19 pandemic that started in Wuhan, Hubei province, China and which already claimed more than 340,000 lives worldwide as of May 23, 2020 (1). It is a single-stranded RNA virus whose complex metabolism remains comparable to RNA viruses such as Influenza virus, some hemorrhagic fever viruses (such as Ebola virus or Hantavirus), Human Immunodeficiency Virus (HIV) and Coxsackievirus (2, 3). COVID-19 is a systemic disease and in addition to the more obvious respiratory symptoms, secondary symptoms that are now known to contribute to COVID-19 associated morbidity and mortality include heart problems like myocarditis (a primary feature of Coxsackievirus infection) (4) and systemic microthrombosis (a feature of hemorrhagic fever viruses) (5). Although few data are available thus far about the interaction between Se, an essential natural trace element, and SARS-CoV-2, RNA virus and Se interactions are well-documented (6-9). We present, firstly, a brief review of how Se deficiency promotes mutations, replication and virulence of different RNA viruses and secondly, the mechanisms by which Se could act in COVID-19 disease spectrum. Finally we discuss the potential links between host Se status and risk factors for severe COVID-19. 


\section{SELENIUM DEFICIENCY PROMOTES MUTATIONS, REPLICATION, AND VIRULENCE OF RNA VIRUSES, AND SELENIUM HAS CLINICAL BENEFIT IN RNA VIRAL INFECTIONS}

\section{Coxsackievirus}

Twenty years ago, Beck and Levander demonstrated that a usually mild Coxsackie virus could become highly virulent in Se deficient mice $(6-8,10)$. Keshan disease is a notable illustration. It is a myocarditis of viral origin (Coxsackievirus) occurring in a well-known Northeast/Southwest belt of China which is deficient in Se (11). Oxidative stress seems to be correlated with the degree of myocardial damage in patients with Keshan disease and selenoenzymes may also be involved in its pathogenesis (12). The prevalence of this viral disease, which at one aspect in time was responsible for thousands of deaths each year, has significantly reduced with the increased intake of Se (13).

\section{Hantavirus}

Hantavirus (of the RNA Bunyaviridae family) can cause hemorrhagic fever with renal syndrome (HFRS) that is a group of clinically similar illnesses including Korean hemorrhagic fever, nephropathia epidemica and epidemic hemorrhagic fever (14).

In China, the incidence of HFRS is six times higher in Sedeficient areas (15). Viral replication was found to be higher in the event of Se deficiency and the intake of Se significantly inhibited the Hantavirus's replication at low viral titers (15). Remarkably, Hou (16) observed an $80 \%$ reduction in mortality in a cohort of 80 patients with Hantavirus epidemic hemorrhagic fever that were treated with a short 10 day intervention of high dose sodium selenite (16).

The combination of the last two cited studies are an important precedent which shows that, similar to Keshan disease/Coxsackievirus, a virus with increased incidence or severity in low Se regions responded clinically to a therapeutic intervention with a Se compound.

\section{Influenza Virus}

During the H1N1 influenza pandemic, Moya et al. (17) showed that their group of patients with H1N1 pneumonia was more Se deficient than the control group (non-H1N1 but presenting influenza-like illness). In addition, patients with H1N1 pneumonia who had a blood Se level considered to be optimal for normal Glutathione Peroxidase (GPx) activity (18) recovered faster and had a better survival rate than the patients with H1N1 pneumonia but with lower Se levels (17).

Abbreviations: COVID-19, Coronavirus Disease 19 caused by SARS-CoV-2; DNA, Deoxyribonucleic acid; EBOV, Ebola virus; GPx, Glutathione Peroxidase; HIV, Human Immunodeficiency Virus; HFRS, Hemorrhagic fever with renal syndrome; mRNA, messenger Ribonucleic acid; NF- $k$ B, Nuclear Factor kappaB; RNA, Ribonucleic acid; ROS, reactive oxygen species; SARS, severe acute respiratory syndrome; SARS-CoV-2, novel coronavirus 2019; Se, Selenium; TxA2, Thromboxane A2; TrxR, Thioredoxin reductase; 3'-UGA, 3'- Uracil Guanine Adenine Stop codon.
Data in mice infected with the H1N1 virus and fed with either a Se deficient diet or supplemented with Se are striking: $75 \%$ mortality in Se deficient mice vs. $25 \%$ in Se supplemented mice (19). Similarly, Nelson et al. (20) showed that in Se deficient mice, increased viral mutations in the influenza virus A/Bangkok/1/79 (H3N2) genome were observed, resulting in a more virulent phenotype (20). Indeed, Se deficient mice and infected with $\mathrm{H} 3 \mathrm{~N} 2$ had more severe pulmonary histological damages than infected mice without Se deficiency.

\section{Human Immunodeficiency Virus Type 1 (HIV-1)}

Unlike the above examples, in which the incidence, virulence or outcome of a viral infection was shown to correlate with Se status in specific geographic region, multiple reports over decades have shown that disease progression or mortality risk in HIV/AIDS is correlated with Se status in specific cohorts $(21,22)$. In addition, a therapeutic benefit of Se supplementation has been demonstrated in a number of clinical trials (23-26). Even in the case of HIV-1, one study was able to associate AIDS-related mortality in the US African-American population as of the year 1990 with Se status based on forage crop Se data (ranked as low, medium, and high) in different US States (27).

\section{Coronavirus SARS-CoV-2}

COVID-19 is a multi-organ disease associated with a high morbidity and high rates of intensive care unit admissions. A recent epidemiological study by Zhang et al. (28) shows striking data comparing recovery rates from COVID-19 in 17 Chinese cities with population Se status (using hair Se data) for which they found a highly significant positive correlation (28): The lower the Se status in a population, the lower the recovery rate from COVID-19. Although this study does not prove causality, data are in the same line as other previously mentioned studies on RNA viruses and Se. However, one notable point in their results was that in the city of Enshi, which has one the highest Se intakes in the world, the recovery rate from COVID-19 was almost triple the average for the rest of the cities in Hubei Province, including Wuhan. This strongly suggests that the Se effect is not only of importance in Se deficient populations, but that having a higher than normal Se status may offer a protective benefit against the detrimental effects of the viral infection. This observation, like the Hou's study cited above for epidemic hemorrhagic fever (16), goes against the conventional wisdom that there is no benefit in Se supplementation above the minimum required dietary intake. These population based data have been recently confirmed in clinical practice in a study by Moghaddam et al. in Germany (29). They showed that serum Se levels were highly correlated with COVID-19 outcome in hospitalized patients. Very low serum Se status was present in $44.4 \%$ of their patients. Sixty five percent of the deceased had low Se vs. $39 \%$ in those who survived. The lowest serum Se were strongly associated with mortality. 


\section{MECHANISMS BY WHICH SODIUM SELENITE COULD ACT IN RNA VIRUS INFECTIONS INCLUDING SARS-CoV-2}

\section{Restoration of the Host Cell Thioredoxin Reductase (TrxR) Biosynthesis}

The TrxR is a major enzyme that contributes to DNA replication, defense against oxidative damage due to oxygen metabolism, and redox signaling (30). Taylor et al. (31) presented computational and in vitro evidence that HIV-1 and the Zaire strain of Ebola virus (EBOV) target cellular selenoprotein mRNAs by RNA:RNA antisense interactions for the purpose of hijacking the selenocysteine insertion sequence ("SECIS element") of the cellular messenger RNA (mRNA) in order to express a viral selenoprotein (32). In both cases, the mRNAs of isoforms of thioredoxin reductase ( $\operatorname{TrxR}$ ) appear to be targeted. They also presented evidence in support of this mechanism via green fluorescent protein reporter gene assays, in which readthrough of the 3'-UGA stop codons of the respective HIV-1 nef protein and EBOV nucleoprotein genes was evident (31). This mechanism would also be expected to lead to down regulation of the targeted TrxR protein, which could contribute to pathogenic effects of the virus, as it could result in increased oxidative stress (32).

Taylor and Ruzicka (33) later presented evidence of similar antisense targeting of several selenoprotein mRNAs, including selenoprotein $\mathrm{P}$ and TrxR1, by Zika virus mRNA, and proposed that the antisense knockdown of TrxR isoforms could be a general mechanism by which RNA viruses can increase the pool of ribonucleotides for viral RNA synthesis, by inhibiting the synthesis of DNA (33). Because of the essential role of TrxR in the thioredoxin system (30), which is a hydrogen donor for the reduction of ribose to 2'-deoxyribose, they proposed that this could be an effective strategy for RNA viruses. Because of the fact that TrxR is a selenoprotein in mammals, this may explain why various RNA viruses, including SARS-CoV-2, have shown a relationship to Se status, as reviewed above.

The antioxidant capacities of the host cell would certainly be affected by TrxR knockdown (9), which could be partially rectified by increasing Se intake to boost the availability of selenocysteine for selenoprotein synthesis. Sodium selenite is a rapidly bio-available form that can cross the blood-brain barrier more readily than other forms of Se. Pharmacological doses could help to rapidly restore the TrxR biosynthesis (34), thereby re-establishing cellular DNA synthesis and antioxidant capacities.

\section{Decrease in Viral-Induced Cell Apoptosis}

Viral infection is associated with oxidative stress through the induction of enzymes that produce harmful reactive oxygen species (ROS) (9). There is an increase of ROS in a cell model infected with the influenza AH1N1 RNA virus (35). Sodium selenite decreases the production of ROS and the induced cell apoptosis in these infected cells (36).

Furthermore, Nuclear Factor kappaB (NF-kB) has antiapoptotic or, on the contrary, apoptotic properties depending on the circumstances (37). RNA viruses can trigger activation of NF$k \mathrm{~B}$ and divert its function to their benefit $(38,39)$. Liao et al. (40) have shown that this NF- $k$ B activation in cells infected with the nucleocapsid protein of SARS-CoV could be responsible, at least in part, for severe inflammatory pulmonary lesions in Severe Acute Respiratory Syndrome (40). In addition, NF- $k$ B pathway activation is a key to various pro-inflammatory cytokines and chemokines production (41). Overproduction of these cytokines can lead to the life threatening "cytokine storm" $(42,43)$

The inhibition of NF- $k$ B induced by SARS-CoV in a mouse model is associated with greater survival (44). Se is wellestablished as an NF- $k \mathrm{~B}$ inhibitor and may play a role in reducing viral-induced apoptosis (45-47) and might contribute to mitigate the cytokine storm linked with severe COVID-19 (48).

\section{Restoring the Host's Selenium Stock}

$\mathrm{Se}$ is incorporated as selenocysteine into selenoproteins which exert immune and anti-inflammatory effects (49). At least 25 selenoproteins have been identified in humans, many of which are involved in antioxidant processes (9). Dietary Se supplementation is associated with increased selenoenzymes activity showing that baseline Se levels in some populations might be insufficient for optimal selenoenzymes activities $(34,50)$.

The use of Se in critically ill patients is a matter of controversy but this essentially applies to bacterial sepsis (51). Although COVID-19 may resemble sepsis, Se potential action in RNA related diseases is quite different (52). Indeed, RNA viruses, including the SARS coronaviruses, likely divert cellular Se for their own selenoproteins $(9,33,53,54)$. Intense viral replication would therefore induce a Se deficiency in the host cell $(33,55,56)$. In this case, an exogenous supply of Se could restore the host "stock" that is essential for the biosynthesis of cellular selenoproteins, particularly those required for antioxidant defense.

\section{Selenium, in Particular as Selenite, Protects Endothelial Cells, and Acts on Blood Platelets Aggregation}

The peculiar feature of COVID-19 is that it has been associated with thrombosis events such as large vessel clots, arterial adn deep vein thrombosis, pulmonary embolism, and microvascular thrombosis, probably due to endothelium dysfunction, platelet activation and inflammation $(57,58)$. It was recently demonstrated that SARS-CoV-2 induces endotheliitis as a result of both direct infection of endothelial cells in various organs and inflammatory response from the host $(59,60)$. Selenoenzymes such as Glutathione peroxidase and TrxR have an important role in the endothelial cell function (61). Oxidative damage can be reduced by selenite in human endothelial cells via a TrxR and GPx induction $(62,63)$.

COVID-19 is also associated with thrombocytopenia $(64,65)$ and an increasing incidence of strokes, even in younger patients, is a worrisome trend in COVID-19 pathology.

Regarding clot formation, Thromboxane A2 (TxA2) formation is a key factor in blood platelet activation and 
aggregation, resulting in blood coagulation/thrombosis formation and leading to recommendations as well as dilemmas of anticoagulant use in Intensive Care Units for COVID-19 patients $(58,66,67)$. Sodium selenite has been shown to have an antiaggregating effect by decreasing TxA2 formation (68). In addition, higher serum Se levels are significantly associated with higher platelet count in healthy adults (69).

Hence, there is considerable potential for Sodium selenite to help reduce damage induced by endotheliitis and the systemic blood clotting that now appears to be a common and key feature of severe COVID-19 (70).

\section{POTENTIAL RELATIONSHIP BETWEEN COVID-19 OUTCOME AND HOST SELENIUM STATUS}

Se plays a key and complex role in the immune system especially in oxidative stress processes, via Thioredoxin, NADPH, and TrxR $(49,71)$. Moreover, it is now well-established that Se deficiency is associated with greater susceptibility to viral RNA infections and more severe outcome.

Besides other associated risk factors for severe COVID-19, Obesity (with Body Mass Index $>30 \mathrm{Kg} / \mathrm{m}^{2}$ ) is now clearly identified as major one $(72,73)$ : the higher the BMI the higher the mortality risk. This important factor might contribute to the, to date, uncontrolled epidemic in the USA and Mexico where $42 \%$ and $30 \%$ of the population is obese, respectively $(74,75)$ and a relatively younger average age of the COVID-19 admitted patients compared to European cohorts (76). Most illnesses tied to worse outcomes in COVID-19 (77) are characterized by an underlying low-grade inflammation and oxidative stress such as obesity and metabolic syndrome (72, 78-81). Adipose tissue is a distinct endocrine organ and capable of synthesizing numerous cytokines such as IL-6, IL-8, and TNF-alpha (82). Obesity is characterized by increased macrophages infiltration in adipose tissue which is proven to be a SARS-Cov-2 reservoir (83). These macrophages can be activated locally by the virus leading to the deleterious production of reactive oxygen/nitrogen species if not counterbalanced by redox homeostasis $(84,85)$. Of note, Se attenuates pro-inflammatory gene expression in macrophages (86). miR-185-5p, a Se sensitive microRNA, was identified to regulate six of eight Glutathione Peroxidase and to control the feedback expression of selenoproteins in obese patients (87). Similarly, obesity is also associated with a reduction of Glutathione Peroxidase 3(GPx3) activity in adipose tissue (88). An recent animal study by Hauffe et al. demonstrated that sodium selenite supplementation in obese mice increased GPx3 activity and insulin receptors/sensitivity in adipose tissue (89). In addition, obesity is often accompanied by cardiovascular impairments such as endothelium dysfunction and arterial stiffness that could favor the endothelium infection by SARSCoV-2 (90). Similarly, cardiac alterations and the prothrombotic propensity in obesity could increase the observed cardiovascular events in intensive care unit COVID-19 patients $(58,91,92)$.

The fact that these pathologies exhibit oxidative stress and inflammation along with endothelium dysfunction and low Se level (93-97), and the relationships described above between Se and RNA viruses suggest a possible link between SARS-CoV-2 infection and Se.

In addition, compared with healthy adults, older subjects are consistently proven to be more vulnerable to COVID19 with atypical clinical presentations $(98,99)$. They are at significantly increased risk of serious complications and mortality: average case fatality ratio of $4-5 \%$ above 60 years of age from international data, and probably up to $14.8 \%$ above 80 years $(100,101)$. Many factors could explain this such as blunted immune response, aging related frailty and multiple chronic co-morbidities along with a degree of malnutrition (102-105). Moreover, senescent fibroblasts are four times more prone to oxidative stress than young cells and consume more Se (106). Interestingly, the addition of Se in these cells, at high concentration, increases Glutathione Peroxidase activity and decreases reactive oxygen species (106). Low or borderline Se level in the elderly people is reported to influence longevity and mortality rate (107-110). In Sweden, $71 \%$ of elderly are Se deficient when admitted to Intensive Care Unit (111). Se supplementation has reduced significantly infections in institutionalized elderly people (110). Similarly, 4 year Se supplementation in Swedish elderly people reduced cardiovascular mortality risk by more than $40 \%$, even 12 years after intervention (112).

\section{DISCUSSION}

In the first part, we reviewed the current evidence on how RNA virus can mutate, replicate and become more virulent in Se-deficient environment. There is now evidence that SARSCoV-2 behaves similarly with the recent study from Zhang et al. (28) showing the link between COVID-19 recovery rate and the Se population status in 17 Chinese cities and Moghaddam et al. pointing at a strong correlation with low Se status and poor outcome in hospitalized patients (29) It is also important to note that SARS-Cov-2 Spike Protein S mutated (D614G) leading to an apparently more infectious strain now dominant in the Western regions as in the US $(113,114)$. Se presents various potential interests that can be applied to COVID-19 $(115,116)$. Evidence suggest that Se helps reducing oxidative stress by restoring selenoenzymes activities such as TrxR in particular (62). Its antioxidant effect would probably be most beneficial as prevention before one gets infected or at the very early stage before severe oxidative stress has arisen like in advanced severe COVID-19. In addition, Se plays a major role through its inhibitory effect on $\mathrm{NF} \mathrm{B}$ signaling, which acts as a central mediator of immune and inflammatory responses notably the pro-inflammatory molecules involved in life-threatening cytokine storm in COVID-19. Furthermore, Se protects endothelial cells function and may play a role in SARS-CoV-2 induced endotheliitis (61). Moreover, its antithrombotic properties are also recognized (68).

In many European countries populations, Se levels are below or borderline the level for optimal Glutathione Peroxidase and 
TABLE 1 | Rationale for potential preventive (Pr) and/or therapeutic (Th) use of selenium (Se) in COVID-19.

\begin{tabular}{ll}
\hline References & Main points \\
\hline $\begin{array}{l}\text { RNA virus } \\
(6,8-11)\end{array}$ & Se deficiency increases mutation, replication, and virulence of RNA viruses \\
$(9,30-32,53,54)$ & $\begin{array}{l}\text { RNA viruses, including the SARS coronaviruses, likely divert cellular Selenium for their own } \\
\text { selenoproteins and knockdown host TrxR/GPx (bioinformatic studies) }\end{array}$ \\
$(13)$ & $\begin{array}{l}\text { Se supplementation decrease Keshan disease (linked to Coxsackie virus) prevalence } \\
(15,16)\end{array}$ \\
$(23-26)$ & Se treatment reduced mortality Hantavirus infection (HFRS) in mice and humans \\
$(28,29)$ & Se supplementation HIV reduces disease progression and mortality \\
& Se deficiency in population and patient-based studies associated with low recovery rate and \\
& mortality of COVID-19
\end{tabular}

\section{Se general action}

(86)

In vivo Se supplementation increases platelet GPx activity and reduces aggregation through
TXA2 inhibition and increased bleeding time
Se protects endothelial cells from oxidative insult
In vitro, Se supplementation protects human endothelial cells from oxidative damage through
TrxR and GPx induction

$(36,45,47)$

(44)

(35)

(36)

Obesity, elderly

(81)

(80)

(87)

(96)

(106)

$(107,110,112)$
In vitro Se attenuates pro-inflammatory gene expression in macrophages

Se mediates inhibition of the activation of the transcription factor NF-kB which regulates genes that encode inflammatory cytokines

in animal study, Se Inhibition of Nf-kB in SARS-Cov infected mice increased survival

Se inhibits the production of ROS in $\mathrm{H} 1 \mathrm{~N} 1$ infected cell models

Se addition in cell media deficient in Se, counteracts ROS damages via GPx activity restoration
Obesity related oxidative stress has deleterious impact on cardiovascular disease (Framingham study)

Obese hosts exhibit delayed and blunted antiviral responses to influenza virus infection

In Bioinformatic study, Se deficiency alters miRNAs (miR-185-5p) that regulate selenoproteins expression (GPx) in oxidative stress and obesity Obesity is tied to reduction of GPx3 activity in adipose tissue

In animal study, Selenite treatment increases GPx3 activity in obese mice

Serum Se level is significantly reduced among morbidly obese

ex vivo study, Oxidative stress is highly increased in senescent fibroblasts that consume more

Se. The addition of Se in these cells, increases GPx activity and decreases ROS

In clinical study, In elderly subjects, the more Se deficiency the higher the mortality rate

In RCT, Se supplementation in elderly reduces viral events and cardiovascular mortality
As $\operatorname{Pr}$ and Th of COVID-19 thrombosis and/or endothelitis and/or inflammatory complications
Se (Th) might modulate NFKB activation in SARS-Cov-2 (cytokine storm)

ROS effects, apoptosis oxidative stress (Th)

Selenoprotein P activity (117). It is estimated that up to a billion people are at risk of Se deficiency worldwide, and this is likely to increase with global warming (118). We have also shown that elderly, especially those with co-morbidities, are particularly prone to Se deficiency and oxidative stress $(104,108,111)$ which may explain, in part, the worse outcome of COVID-19 in this subpopulation.

Sodium selenite $(\mathrm{Na} 2 \mathrm{SeO} 3)$ is readily available and is a compound already present in pharmacopeia in human diseases (in some countries as selenious acid, for addition to total parenteral nutrition solutions, as well as treatment of deficiency) and whose short-term toxicity is minimal, if not absent, and well-documented. It is rapidly incorporated and TrxR activity can increase in a few hours after supplementation $(34,111)$.

Pending the development of an effective vaccine, while faced with the deadly COVID-19 pandemic and especially the unprecedented pressure it exerts on the health care system, the potential use and effectiveness (or not) of sodium selenite must be urgently tested and documented in outpatient as well as inpatient settings.

Based on this review and summarized in Table 1, we propose a simple and readily feasible approach in line with the described clinical course of COVID-19 (100, 102, 119) consisting of: 
- Prevention (Pr), in order to contribute coping with the disease: supplementing populations at risk of developing severe COVID-19 before they become infected. Priority target population would be represented by the elderly with co-morbidities and the obese. The issue of long term Se supplementation dosage has been controversial as its metabolism might involve a U-shape relation especially regarding glucose homeostasis (120). Therefore, long term supplementation needs special attention and it might be recommended to monitor glycemia after a few weeks. However, recent studies have been reassuring regarding dosages $<300$ mcg notably for type 2 diabetes and prostate cancer (121-125). Long term 200 mcg Selenium supplementation in randomized controlled trials in HIV infection has been shown to be well-tolerated (2426). In addition, 200 micrograms of Se daily has been given in the elderly for years with significant positive results lowering viral infection rates and cardiovascular mortality (110, 112). The American national institute of medicine recommends Se supplementations of $<400$ $\mathrm{mcg} /$ daily (126). Therefore, the approach of $200 \mathrm{mcg}$ Se supplementation daily for 3 weeks followed by a maintenance dose of $\leq 200 \mathrm{mcg}$ throughout the active circulation of SARS-Cov-2 seems safe and sound considering the high mortality risk related to COVID-19 in these vulnerable subgroups.

- Documentation of serum Se status whenever possible in hospitalized COVID-19 patients.

- Treatment (Th) of symptomatic patients: systematic addition of Se in symptomatic out patients at all ages and Sodium selenite upon hospital admission as soon as possible at the earliest stage before the deadly cytokine storm arises.

However, whichever stage of COVID-19, Sodium selenite might still have some benefits as an adjuvant therapy to tackle endotheliitis, coagulopathy and microthrombotic events and to restore some selenoenzymes activities reducing oxidative stress $(61,62,68)$.

To counteract SARS-Cov-2 effects Se has to be given well above nutritional recommended daily allowance (RDA) i.e., 200 to 400 micrograms of Se element per day, which corresponds approximately to 600 to 1,200 micrograms of sodium selenite. Previous studies on Hantavirus infection and sepsis in ICU have demonstrated good tolerance of higher dosages of selenite for acute treatment $(16,51,127)$. This would seem appropriate and safe for a very short period of two to three weeks in order to replenish selenium stock (29) in this impending life-threatening condition. In the hospital, the intravenous form is undoubtedly more suitable given a large number of digestive disorders in the context of COVID-19.

\section{REFERENCES}

1. Coronavirus Resource Center, Johns Hopkins University \& Medicine. COVID-19 Data in Motion: Monday, August 17, 2020. (2020). Available online at: https://coronavirus.jhu.edu/map.html (accessed May 23, 2020).
This mini review is about $\mathrm{Se}$ and its potential use in RNA virus with a focus on SARS-Cov-2. However, other factors have to be taken into account including at nutritional level. However, they do not fit in the scope of this review. We must cite for example the potential role of vitamin $\mathrm{D}$, zinc, and poly unsaturated fatty acids (PUFA) that need proper studies and documentation in this context $(128,129)$.

\section{CONCLUSION}

Se deficiency environments favor mutation, replication and virulence of RNA viruses. The fact that both, a link between population Se status in various Chinese cities and COVID-19 recovery rates has been described and, low serum Se status in German hospitalized COVID-19 patients has been associated with more severe outcome, are striking data showing that SARS-CoV-2 might be influenced by Se status, like other RNA viruses. Se induces antioxidant selenoenzymes activity and might rebalance the host response. Se as a NF- $k$ B inhibitor plays a role in COVID-19 progression and acts as an immunomodulatory and anti-inflammatory micronutrient Se. Moreover, Se might reduce the effect of SARS-CoV-2 on vascular endothelial cells and aggregation of platelets. Oxidative state in COVID-19 is a common feature especially in elderly and obese patients both at risk of severe outcome. Here, by reducing oxidative stress, Se might have an important role to play. Sodium selenite is cheap and readily available. Pending the development of an effective vaccine, while faced with the deadly COVID-19 pandemic and especially the unprecedented pressure it exerts on the health care system, the potential use and effectiveness (or not) of sodium selenite must be urgently tested and documented in outpatient as well as inpatient settings. Similarly, as some countries enter the post-confinement era, implementing a preventive Se supplementation, especially in the elderly represent a sound, safe and feasible strategy. Se with its pleiotropic effects in COVID-19 disease sprectrum may become an important research topic in human health.

\section{AUTHOR CONTRIBUTIONS}

LH drafted the manuscript. LH and BR contributed equally on the final manuscript. All authors contributed to the article and approved the submitted version.

\section{ACKNOWLEDGMENTS}

We would like to thank Timothy Andrew Houtman for his kind editorial assistance.

2. Carrasco-Hernandez R, Jácome R, López Vidal Y, Ponce de León S. Are RNA viruses candidate agents for the next global pandemic? A review. ILAR J. (2017) 58:343-58. doi: 10.1093/ilar/ilx026

3. Lu R, Zhao $\mathrm{X}$, Li J, Niu P, Yang B, Wu H, et al. Genomic characterisation and epidemiology of 2019 novel coronavirus: 
implications for virus origins and receptor binding. Lancet. (2020) 395:565-74. doi: 10.1016/S0140-6736(20)30251-8

4. Whitton JL. Immunopathology during coxsackievirus infection. Springer Semin Immunopathol. (2002) 24:201-13. doi: 10.1007/s00281-002-0100-4

5. Chang J. Pathogenesis of ebola viral haemorrhagic fever: TTPlike syndrome associated with hepatic coagulopathy based on "two activation theory of the endothelium". J Prev Infect Control. (2017) 3:1-7. doi: 10.21767/2471-9668.100029

6. Levander OA, Beck MA. Selenium and viral virulence. Br Med Bull. (1999) 55:528-33. doi: 10.1258/0007142991902592

7. Levander OA. Nutrition and newly emerging viral diseases: an overview. $J$ Nutr. (1997) 127:948-50S. doi: 10.1093/jn/127.5.948S

8. Beck MA, Levander OA, Handy J. Selenium deficiency and viral infection. $J$ Nutr. (2003) 133:1463-7S. doi: 10.1093/jn/133.5.1463S

9. Guillin OM, Vindry C, Ohlmann T, Chavatte L. Selenium, selenoproteins and viral infection. Nutrients. (2019) 11:2101. doi: 10.3390/nu11092101

10. Levander OA, Beck MA. Interacting nutritional and infectious etiologies of Keshan disease: insights from coxsackie virus B-induced myocarditis in mice deficient in selenium or vitamin E. Biol Trace Elem Res. (1997) 56:5-21. doi: 10.1007/BF02778980

11. Ren L-Q. Coxsackievirus $\mathrm{B}_{3}$ infection and its mutation in Keshan disease. World J Gastroenterol. (2004) 10:3299. doi: 10.3748/wjg.v10.i22.3299

12. Pei J, Fu W, Yang L, Zhang Z, Liu Y. Oxidative stress is involved in the pathogenesis of Keshan disease (an endemic dilated cardiomyopathy) in China. Oxid Med Cell Longev. (2013) 2013:1-5. doi: 10.1155/2013/474203

13. Li Q, Liu M, Hou J, Jiang C, Li S, Wang T. The prevalence of Keshan disease in China. Int J Cardiol. (2013) 168:1121-6. doi: 10.1016/j.ijcard.2012.11.046

14. Centers for Disease Control and Prevention. Hemorrhagic Fever With Renal Syndrome HFRS. (2017). Available online at: https://www.cdc.gov/ hantavirus/hfrs/index.html (accessed May 20, 2020).

15. Fang L-Q, Goeijenbier M, Zuo S-Q, Wang L-P, Liang S, Klein S, et al. The Association between Hantavirus infection and selenium deficiency in Mainland China. Viruses. (2015) 7:333-51. doi: 10.3390/v7010333

16. Hou J-C. Inhibitory effect of selenite and other antioxidants on complementmediated tissue injury in patients with epidemic hemorrhagic fever. Biol Trace Elem Res. (1997) 56:125-30. doi: 10.1007/BF02778988

17. Moya M, Bautista EG, Velázquez-González A, Vázquez-Gutiérrez F, Tzintzun G, García-Arreola ME, et al. Potentially-toxic and essential elements profile of AH1N1 patients in Mexico city. Sci Rep. (2013) 3:1284. doi: 10.1038/srep01284

18. Combs GF. Biomarkers of selenium status. Nutrients. (2015) 7:220936. doi: 10.3390/nu7042209

19. Yu L, Sun L, Nan Y, Zhu L-Y. Protection from H1N1 influenza virus infections in mice by supplementation with selenium: a comparison with selenium-deficient mice. Biol Trace Elem Res. (2011) 141:25461. doi: 10.1007/s12011-010-8726-x

20. Nelson HK, Shi Q, Van Dael P, Schiffrin EJ, Blum S, Barclay D, et al. Host nutritional selenium status as a driving force for influenza virus mutations. FASEB J. (2001) 15:1846-8. doi: 10.1096/fj.01-0108com

21. Constans J, Pellegrin J-L, Sergeant C, Simonoff M, Pellegrin I, Fleury $\mathrm{H}$, et al. Serum selenium predicts outcome in HIV infection. J Acquir Immune Defic Syndr Hum Retrovirol. (1995) 10:392. doi: 10.1097/00042560-199511000-00015

22. Baum MK, Shor-Posner G, Lai S, Zhang G, Lai H, Fletcher MA, et al. High risk of HIV-related mortality is associated with selenium deficiency. J Acquir Immune Defic Syndr Hum Retrovirol. (1997) 15:3704. doi: 10.1097/00042560-199708150-00007

23. Jiamton S, Pepin J, Suttent R, Filteau S, Mahakkanukrauh B, Hanshaoworakul W, et al. A randomized trial of the impact of multiple micronutrient supplementation on mortality among $\mathrm{HIV}$-infected individuals living in Bangkok. AIDS. (2003) 17:2461-9. doi: 10.1097/00002030-200311210-00008

24. Hurwitz BE. Suppression of human immunodeficiency virus type 1 viral load with selenium supplementation: a randomized controlled trial. Arch Intern Med. (2007) 167:148. doi: 10.1001/archinte.167.2.148

25. Baum MK, Campa A, Lai S, Sales Martinez S, Tsalaile L, Burns P, et al. Effect of micronutrient supplementation on disease progression in asymptomatic, antiretroviral-naive, hiv-infected adults in botswana: a randomized clinical trial. JAMA. (2013) 310:2154. doi: 10.1001/jama.2013.280923

26. Kamwesiga J, Mutabazi V, Kayumba J, Tayari J-CK, Uwimbabazi JC, Batanage G, et al. Effect of selenium supplementation on CD4+ Tcell recovery, viral suppression and morbidity of HIV-infected patients in Rwanda: a randomized controlled trial. AIDS. (2015) 29:104552. doi: 10.1097/QAD.0000000000000673

27. Cowgill UM. The distribution of selenium and mortality owing to acquired immune deficiency syndrome in the continental United States. Biol Trace Elem Res. (1997) 56:43-61. doi: 10.1007/BF02778983

28. Zhang J, Taylor EW, Bennett K, Saad R, Rayman MP. Association between regional selenium status and reported outcome of COVID-19 cases in China. Am J Clin Nutr. (2020) 11:1297-9. doi: 10.1093/ajcn/nqaa095

29. Moghaddam A, Heller RA, Sun Q, Seelig J, Cherkezov A, Seibert, et al. Selenium deficiency is associated with mortality risk from COVID-19. Nutrients. (2020) 12:2098. doi: 10.3390/nu12072098

30. Arnér ESJ, Holmgren A. Physiological functions of thioredoxin and thioredoxin reductase: thioredoxin and thioredoxin reductase. Eur J Biochem. (2000) 267:6102-9. doi: 10.1046/j.1432-1327.2000.0 1701.x

31. Taylor EW, Ruzicka JA, Premadasa L. Theoretical and Experimental Evidence for RNA:RNA Antisense Tethering of Thioredoxin Reductase mRNAs by Ebola and HIV-1 for viral Selenoprotein Synthesis. ResearchGate (2015). Available online at: http://rgdoi.net/10.13140/RG.2.2.10237.51683

32. Taylor EW, Ruzicka JA, Premadasa L, Zhao L. Cellular selenoprotein mRNA tethering via antisense interactions with ebola and HIV-1 mRNAs may impact host selenium biochemistry. Curr Top Med Chem. (2016) 16:15305. doi: 10.2174/1568026615666150915121633

33. Taylor EW, Ruzicka JA. Antisense inhibition of selenoprotein synthesis by Zika virus may contribute to neurological disorders and microcephaly by mimicking SePP1 knockout and the genetic disease progressive cerebello-cerebral atrophy. Bull World Health Organ. (2016) doi: 10.2471/BLT.16.182071. [Epub ahead of print].

34. Berggren M, Gallegos A, Gasdaska J, Powis G. Cellular thioredoxin reductase activity is regulated by selenium. Anticancer Res. (1997) 17:3377-80.

35. Gong G, Li Y, He K, Yang Q, Guo M, Xu T, et al. The inhibition of H1N1 influenza induced apoptosis by sodium selenite through ROS-mediated signaling pathways. RSC Adv. (2020) 10:8002-7. doi: 10.1039/C9RA0 9524A

36. Baker RD Jr., Baker SS, Rao R. Selenium deficiency in tissue culture: implications for oxidative metabolism. J Pediatr Gastroenterol Nutr. (1998) 27:387-92. doi: 10.1097/00005176-199810000-00003

37. Khandelwal N, Simpson J, Taylor G, Rafique S, Whitehouse A, Hiscox J, et al. Nucleolar NF-кB/RelA mediates apoptosis by causing cytoplasmic relocalization of nucleophosmin. Cell Death Differ. (2011) 18:1889903. doi: 10.1038/cdd.2011.79

38. Kumar N, Xin Z, Liang $\mathrm{Y}$, Ly $\mathrm{H}$, Liang $\mathrm{Y}$. NF- $\kappa \mathrm{B}$ signaling differentially regulates influenza virus RNA synthesis. J Virol. (2008) 82:9880-9. doi: 10.1128/JVI.00909-08

39. Droebner K, Reiling SJ, Planz O. Role of hypercytokinemia in NF-кB p50-deficient mice after H5N1 influenza A virus infection. J Virol. (2008) 82:11461-6. doi: 10.1128/JVI.01071-08

40. Liao Q-J, Ye L-B, Timani KA, Zeng Y-C, She Y-L, Ye L, et al. Activation of NF-kappaB by the full-length nucleocapsid protein of the SARS coronavirus. Acta Biochim Biophys Sin. (2005) 37:607-12. doi: 10.1111/j.1745-7270.2005.00082.x

41. Liu T, Zhang L, Joo D, Sun SC. NF-кB signaling in inflammation. Signal Transduct Target Ther. (2017) 2:17023. doi: 10.1038/sigtrans.2017.23

42. Ye Q, Wang B, Mao J. The pathogenesis and treatment of the 'Cytokine Storm' in COVID-19. J Infect. (2020) 80:60713. doi: 10.1016/j.jinf.2020.03.037

43. Song P, Wei L, Xie J, Hou Y, You C. Cytokine storm induced by SARS-CoV-2. Clin Chim Acta. (2020) 509:280-7. doi: 10.1016/j.cca.2020.06.017

44. DeDiego ML, Nieto-Torres JL, Regla-Nava JA, Jimenez-Guardeno JM, Fernandez-Delgado R, Fett C, et al. Inhibition of NF-kappaB-mediated inflammation in severe acute respiratory syndrome coronavirus-infected mice increases survival. J Virol. (2014) 88:913-24. doi: 10.1128/JVI.02576-13 
45. Maehira F, Miyagi I, Eguchi Y. Selenium regulates transcription factor NF$\kappa \mathrm{B}$ activation during the acute phase reaction. Clin Chim Acta. (2003) 334:163-71. doi: 10.1016/S0009-8981(03)00223-7

46. Kretz-Remy C, Arrigo A-P. Selenium: a key element that controls NF- $\kappa \mathrm{B}$ activation and $\mathrm{I} \kappa \mathrm{B} \alpha$ half life. BioFactors. (2001) 14:117-25. doi: 10.1002/biof.5520140116

47. Youn H-S, Lim HJ, Choi YJ, Lee JY, Lee M-Y, Ryu J-H. Selenium suppresses the activation of transcription factor NF- $\mathrm{B}$ and IRF3 induced by TLR3 or TLR4 agonists. Int Immunopharmacol. (2008) 8:495501. doi: 10.1016/j.intimp.2007.12.008

48. Hirano T, Murakami M. COVID-19: a new virus, but a familiar receptor and cytokine release syndrome. Immunity. (2020) 52:7313. doi: 10.1016/j.immuni.2020.04.003

49. Rayman MP. Selenium and human health. Lancet. (2012) 379:125668. doi: 10.1016/S0140-6736(11)61452-9

50. Brown KM, Pickard K, Nicol F, Beckett GJ, Duthie GG, Arthur JR. Effects of organic and inorganic selenium supplementation on selenoenzyme activity in blood lymphoctyes, granulocytes, platelets and erythrocytes. Clin Sci. (2000) 98:593-9. doi: 10.1042/CS19990276

51. Zhao Y, Yang M, Mao Z, Yuan R, Wang L, Hu X, et al. The clinical outcomes of selenium supplementation on critically ill patients: a meta-analysis of randomized controlled trials. Medicine. (2019) 98:e15473. doi: 10.1097/MD.0000000000015473

52. Li X, Geng $\mathrm{M}$, Peng $\mathrm{Y}$, Meng L, Lu S. Molecular immune pathogenesis and diagnosis of COVID-19. J Pharm Anal. (2020) 10:102-8. doi: 10.1016/j.jpha.2020.03.001

53. Zhang W, Ramanathan CS, Nadimpalli RG, Bhat AA, Cox AG, Taylor EW. Selenium-dependent glutathione peroxidase modules encoded by RNA viruses. Biol Trace Elem Res. (1999) 70:97-116. doi: 10.1007/BF02783852

54. Taylor EW, Zhao L, Zhang J. Genomic analysis of SARS coronavirus reveals two hidden genes whose predicted functions suggest a molecular basis for selenium-related abnormalities in SARS. In: International Symposium on SARS 2003. Beijing (2003).

55. Zhao L, Cox AG, Ruzicka JA, Bhat AA, Zhang W, Taylor EW. Molecular modeling and in vitro activity of an HIV-1-encoded glutathione peroxidase. Proc Natl Acad Sci USA. (2000) 97:6356-61. doi: 10.1073/pnas.97.12.6356

56. Taylor EW. Selenium and viral diseases: facts and hypotheses. J Orthomol Med. (1997) 12:227-39.

57. Bikdeli B, Madhavan MV, Jimenez D, Chuich T, Dreyfus I, Driggin E, et al. COVID-19 and thrombotic or thromboembolic disease: implications for prevention, antithrombotic therapy, and follow-up. J Am Coll Cardiol. (2020)75:2950-73. doi: 10.1016/j.jacc.2020.04.031

58. Klok FA, Kruip MJHA, van der Meer NJM, Arbous MS, Gommers DAMPJ, Kant KM, et al. Incidence of thrombotic complications in critically ill ICU patients with COVID-19. Thromb Res. (2020) 191:1457. doi: 10.1016/j.thromres.2020.04.013

59. Varga Z, Flammer AJ, Steiger P, Haberecker M, Andermatt R, Zinkernagel AS, et al. Endothelial cell infection and endotheliitis in COVID-19. Lancet. (2020) 395:1417-8. doi: 10.1016/S0140-6736(20)30937-5

60. Ackermann M, Verleden SE, Kuehnel M, Haverich A, Welte T, Laenger F. et al. Pulmonary vascular endothelialitis, thrombosis, and angiogenesis in Covid-19. N Engl J Med. (2020) 383:120-8. doi: 10.1056/NEJMoa2015432

61. Brigelius-Flohé R, Banning A, Schnurr K. Selenium-dependent enzymes in endothelial cell function. Antioxid Redox Signal. (2003) 5:20515. doi: 10.1089/152308603764816569

62. Miller S, Walker SW, Arthur JR, Nicol F, Pickard K, Lewin MH, et al. Selenite protects human endothelial cells from oxidative damage and induces thioredoxin reductase. Clin Sci Lond Engl. (2001) 100:54350. doi: 10.1042/CS20000299

63. Lewin MH, Arthur JR, Riemersma RA, Nicol F, Walker SW, Millar EM. Selenium supplementation acting through the induction of thioredoxin reductase and glutathione peroxidase protects the human endothelial cell line EAhy926 from damage by lipid hydroperoxides. Biochim Biophys Acta. (2002) 1593:85-92. doi: 10.1016/S0167-4889(02)00333-6

64. Chen N, Zhou M, Dong X, Qu J, Gong F, Han Y, et al. Epidemiological and clinical characteristics of 99 cases of 2019 novel coronavirus pneumonia in Wuhan, China: a descriptive study. Lancet. (2020) 395:50713. doi: $10.1016 /$ S0140-6736(20)30211-7
65. Lippi G, Plebani M, Henry BM. Thrombocytopenia is associated with severe coronavirus disease 2019 (COVID-19) infections: a meta-analysis. Clin Chim Acta. (2020) 506:145-8. doi: 10.1016/j.cca.2020.03.022

66. Perona G, Schiavon R, Guidi GC, Veneri D, Minuz P. Selenium dependent glutathione peroxidase: a physiological regulatory system for platelet function. Thromb Haemost. (1990) 64:312-8. doi: 10.1055/s-0038-16 47308

67. Sangkuhl K, Shuldiner AR, Klein TE, Altman RB. Platelet aggregation pathway. Pharmacogenet Genomics. (2011) 21:51621. doi: 10.1097/FPC.0b013e3283406323

68. Ersöz G, Yakaryilmaz A, Turan B. Effect of sodium selenite treatment on platelet aggregation of streptozotocin-induced diabetic rats. Thromb Res. (2003) 111:363-7. doi: 10.1016/S0049-3848(03)00338-4

69. Qayyum R. Serum selenium levels are associated with blood platelet count in US Adults. J Hosp Med. (2014) 9(Suppl.2).

70. Manne BK, Denorme F, Middleton EA, Portier I, Rowley JW, Stubben CJ, et al. Platelet gene expression and function in COVID-19 patients. Blood. (2020). doi: 10.1182/blood.2020007214. [Epub ahead of print].

71. Avery J, Hoffmann P. Selenium, selenoproteins, and immunity. Nutrients. (2018) 10:1203. doi: 10.3390/nu10091203

72. Yang J, Zheng Y, Gou X, Pu K, Chen Z, Guo Q, et al. Prevalence of comorbidities and its effects in patients infected with SARS-CoV-2: a systematic review and meta-analysis. Int J Infect Dis. (2020) 94:915. doi: 10.1016/j.ijid.2020.03.017

73. Sattar N, McInnes IB, McMurray JJV. Obesity a risk factor for severe COVID-19 infection: multiple potential mechanisms. Circulation. (2020) 142:4-6. doi: 10.1161/CIRCULATIONAHA.120.0 47659

74. Chiappetta S, Sharma AM, Bottino V, Stier C. COVID-19 and the role of chronic inflammation in patients with obesity. Int J Obes. (2020) 44:17902. doi: 10.1038/s41366-020-0597-4

75. Center of Disease Control. Overweight and Obesity - Data and Statistics. Available online at: https://www.cdc.gov/obesity/data/adult.html (accessed July 11, 2020).

76. Hernández-Garduño E. Obesity is the comorbidity more strongly associated for Covid-19 in Mexico. A case-control study. Obes Res Clin Pract. (2020). doi: 10.1016/j.orcp.2020.06.001

77. Kass DA, Duggal P, Cingolani O. Obesity could shift severe COVID-19 disease to younger ages. Lancet. (2020) 395:15445. doi: 10.1016/S0140-6736(20)31024-2

78. Esser N, Legrand-Poels S, Piette J, Scheen AJ, Paquot N. Inflammation as a link between obesity, metabolic syndrome and type 2 diabetes. Diabetes Res Clin Pract. (2014) 105:141-50. doi: 10.1016/j.diabres.2014.04.006

79. Roberts CK, Sindhu KK. Oxidative stress and metabolic syndrome. Life Sci. (2009) 84:705-12. doi: 10.1016/j.lfs.2009.02.026

80. Honce R, Schultz-Cherry S. Impact of obesity on influenza A virus pathogenesis, immune response, and evolution. Front Immunol. (2019) 10:1071. doi: 10.3389/fimmu.2019.01071

81. Keaney JF Jr., Larson MG, Vasan RS, Wilson P, Lipinska I, Corey $\mathrm{D}$, et al. Obesity and systemic oxidative stress: clinical correlates of oxidative stress in the Framingham Study. Arterioscler Thromb Vasc Biol. (2003) 23:434-9. doi: 10.1161/01.ATV.0000058402. 34138.11

82. Coppack SW. Pro-inflammatory cytokines and adipose tissue. Proc Nutr Soc. (2001) 60:349-56. doi: 10.1079/PNS2001110

83. Ryan PM, Caplice NM. Is adipose tissue a reservoir for viral spread, immune activation, and cytokine amplification in coronavirus disease 2019. Obesity. (2020) 28:1191-4. doi: 10.1002/oby.22843

84. Mosser DM. The many faces of macrophage activation. J Leukoc Biol. (2003) 73:209-12. doi: 10.1189/jlb.0602325

85. Zeyda M, Farmer D, Todoric J, Aszmann O, Speiser M, Gyori G, et al. Human adipose tissue macrophages are of an anti-inflammatory phenotype but capable of excessive pro-inflammatory mediator production. Int J Obes. (2007) 31:1420-8. doi: 10.1038/sj.ijo.0803632

86. Vunta H, Belda BJ, Arner RJ, Channa Reddy C, Vanden Heuvel JP, Sandeep Prabhu, K. Selenium attenuates pro-inflammatory gene expression in macrophages. Mol Nutr Food Res. (2008) 52:1316-23. doi: 10.1002/mnfr.200700346 
87. Matoušková $\mathrm{P}$, Hanousková $\mathrm{B}$, Skálová L. MicroRNAs as potential regulators of glutathione peroxidases expression and their role in obesity and related pathologies. Int J Mol Sci. (2018) 19:1199. doi: 10.3390/ijms19041199

88. Langhardt J, Flehmig G, Klöting N, Lehmann S, Ebert T, Kern M, et al. Effects of weight loss on glutathione peroxidase 3 serum concentrations and adipose tissue expression in human obesity. Obes Facts. (2018) 11:47590. doi: $10.1159 / 000494295$

89. Hauffe R, Stein V, Chudoba C, Flore T, Rath M, Ritter K et al. GPx3 dysregulation impacts adipose tissue insulin receptor expression and sensitivity. JCI Insight. (2020) 5:e136283. doi: 10.1172/jci.insight.136283

90. Blokhin IO, Lentz SR. Mechanisms of thrombosis in obesity. Curr Opin Hematol. (2013) 20:437-44. doi: 10.1097/MOH.0b013e3283634443

91. Korakas E, Ikonomidis I, Kousathana F, Balampanis K, Kountouri A, Raptis A, et al. Obesity and COVID-19: immune and metabolic derangement as a possible link to adverse clinical outcomes. Am J Physiol Endocrinol Metab. (2020) 319:E105-9. doi: 10.1152/ajpendo.00198.2020

92. Rico-Mesa JS, Rosas D, Ahmadian-Tehrani A, White A, Anderson AS, Chilton R. The role of anticoagulation in COVID-19-induced hypercoagulability. Curr Cardiol Rep. (2020) 22:53. doi: 10.1007/s11886-020-01328-8

93. Larvie D, Armah D. Relationship between selenium and hematological markers in young adults with normal weight or overweight/obesity. Antioxidants. (2019) 8:463. doi: 10.3390/antiox 8100463

94. Hosseini B, Saedisomeolia A, Allman-Farinelli M. Association between antioxidant intake/status and obesity: a systematic review of observational studies. Biol Trace Elem Res. (2017) 175:287-97. doi: 10.1007/s12011-016-0785-1

95. Mutakin, Meiliana A, Wijaya A, Kobayashi K, Yamazaki C, Kameo S, et al. Association between selenium nutritional status and metabolic risk factors in men with visceral obesity. J Trace Elem Med Biol. (2013) 27:1126. doi: 10.1016/j.jtemb.2012.09.006

96. Alasfar F, Ben-Nakhi M, Khoursheed M, Kehinde EO, Alsaleh M. Selenium is significantly depleted among morbidly obese female patients seeking bariatric surgery. Obes Surg. (2011) 21:1710-3. doi: 10.1007/s11695-011-0458-2

97. Kimmons JE, Blanck HM, Tohill BC, Zhang J, Khan LK. Associations between body mass index and the prevalence of low micronutrient levels among US adults. Med Gen Med. (2006) 8:59.

98. Nikolich-Zugich J, Knox KS, Rios CT, Natt B, Bhattacharya D, Fain MJ. SARS-CoV-2 and COVID-19 in older adults: what we may expect regarding pathogenesis, immune responses, and outcomes. GeroScience. (2020) 42:50514. doi: 10.1007/s11357-020-00186-0

99. Godaert L, Proye E, Demoustier-Tampere D, Coulibaly PS, Hequet F, Dramé M. Clinical characteristics of older patients: the experience of a geriatric short-stay unit dedicated to patients with COVID-19 in France. J Infect. (2020) 81:e93-e94. doi: 10.1016/j.jinf.2020.04.009

100. Verity R, Okell LC, Dorigatti I, Winskill P, Whittaker C, Imai N, et al. Estimates of the severity of coronavirus disease 2019: a model-based analysis. Lancet Infect Dis. (2020) 20:669-77. doi: 10.1016/S1473-3099(20)30243-7

101. The OpenSAFELY Collaborative, Williamson E, Walker AJ, Bhaskaran KJ, Bacon S, Bates C, et al. OpenSAFELY: factors associated with COVID-19-related hospital death in the linked electronic health records of 17 million adult NHS patients. MedRxiv [Preprint]. (2020). doi: 10.1101/2020.05.06.20092999

102. Liu K, Chen Y, Lin R, Han K. Clinical features of COVID-19 in elderly patients: a comparison with young and middle-aged patients. J Infect. (2020) 80:e14-18. doi: 10.1016/j.jinf.2020.03.005

103. Weiskopf D, Weinberger B, Grubeck-Loebenstein B. The aging of the immune system. Transpl Int. (2009) 22:104150. doi: 10.1111/j.1432-2277.2009.00927.x

104. Cui H, Kong Y, Zhang H. Oxidative stress, mitochondrial dysfunction, and aging. J Signal Transduct. (2012) 2012:1-13. doi: 10.1155/2012/646354

105. Kaiser M, Bandinelli S, Lunenfeld B. Frailty and the role of nutrition in older people. A review of the current literature. Acta Bio Med Atenei Parm. (2010) 81(Suppl. 1):37-45.

106. Ghneim H. Selenium concentrations for maximisation of thioredoxin reductase 2 activity and upregulation of its gene transcripts in senescent human fibroblasts. Antioxidants. (2017) 6:83. doi: 10.3390/antiox6040083
107. Alehagen U, Johansson P, Björnstedt M, Rosén A, Post C, Aaseth J. Relatively high mortality risk in elderly Swedish subjects with low selenium status. Eur J Clin Nutr. (2016) 70:91-6. doi: 10.1038/ejcn.2 015.92

108. González S, Huerta JM, Fernández S, Patterson ÁM, Lasheras C. Life-quality indicators in elderly people are influenced by selenium status. Aging Clin Exp Res. (2007) 19:10-5. doi: 10.1007/BF033 25205

109. Robberecht H, De Bruyne T, Davioud-Charvet E, Mackrill J, Hermans N. Selenium status in elderly people: longevity and age-related diseases. Curr Pharm Des. (2019) 25:1694-706. doi: 10.2174/13816128256661907011 44709

110. Girodon F, Lombard M, Galan P, Brunet-Lecomte P, Monget A-L, Arnaud J, et al. Effect of micronutrient supplementation on infection in institutionalized elderly subjects: a controlled trial. Ann Nutr Metab. (1997) 41:98-107. doi: 10.1159/000177984

111. Broman LM, Bernardson A, Bursell K, Wernerman J, Fläring U, Tjäder I. Serum selenium in the critically ill: profile and supplementation in a depleted region. Acta Anaesthesiol Scand. (2020) 64:803-9. doi: 10.1111/aas.13573

112. Alehagen U, Aaseth J, Alexander J, Johansson P. Still reduced cardiovascular mortality 12 years after supplementation with selenium and coenzyme Q10 for four years: a validation of previous 10-year follow-up results of a prospective randomized double-blind placebo-controlled trial in elderly. PLOS ONE. (2018) 13:e0193120. doi: 10.1371/journal.pone.0193120

113. Korber B, Fischer WM, Gnanakaran S, Yoon H, Theiler J, Abfalterer $\mathrm{W}$ et al. Tracking changes in SARS-CoV-2 spike: evidence that D614G increases infectivity of the COVID-19 virus. Cell. (2020) 82:1-16. doi: 10.1016/j.cell.2020.06.043

114. Hu J, He CL, Gao QZ, Zhang GJ, Cao XX, Long QL, et al. D614G mutation of SARS-CoV-2 spike protein enhances viral infectivity. bioRxiv [Preprint]. (2020) doi: 10.1101/2020.06.20.161323

115. Kieliszek M, Lipinski B. Selenium supplementation in the prevention of coronavirus infections (COVID-19). Med Hypotheses. (2020) 143:109878. doi: 10.1016/j.mehy.2020.109878

116. Fakhrolmobasheri M, Nasr-Esfahany Z, Khanahmad H, Zeinalian M. Selenium supplementation can relieve the clinical complications of COVID19 and other similar viral infections. Int J Vitam Nutr Res. (2020) 13. doi: 10.1024/0300-9831/a000663

117. Winther KH, Rayman MP, Bonnema SJ, Hegedüs L. Selenium in thyroid disorders - essential knowledge for clinicians. Nat Rev Endocrinol. (2020) 16:165-76. doi: 10.1038/s41574-019-0311-6

118. Jones GD, Droz B, Greve P, Gottschalk P, Poffet D, McGrath SP, et al. Selenium deficiency risk predicted to increase under future climate change. Proc Natl Acad Sci USA. (2017) 114:2848-53. doi: 10.1073/pnas.16115 76114

119. Zhou F, Yu T, Du R, Fan G, Liu Y, Liu Z, et al. Clinical course and risk factors for mortality of adult inpatients with COVID-19 in Wuhan, China: a retrospective cohort study. Lancet. (2020) 395:105462. doi: 10.1016/S0140-6736(20)30566-3

120. Prabhu KS, Lei XG. Selenium. Adv Nutr. (2016) 7:41517. doi: 10.3945/an.115.010785

121. Jacobs ET, Lance P, Mandarino LJ, Ellis NA, Chow HHS, Foote $J$, et al. Selenium supplementation and insulin resistance in a randomized, clinical trial. BMJ Open Diabetes Research Care. (2019) 7:e000613. doi: 10.1136/bmjdrc-2018-000613

122. Rayman MP, Winther KH, Pastor-Barriuso R, Cold F, Thvilum M, Stranges $\mathrm{S}$ et al. Effect of long-term selenium supplementation on mortality: results from a multiple-dose, randomised controlled trial. Free Radic Biol Med. (2018) 127:46-54. doi: 10.1016/j.freeradbiomed.2018. 02.015

123. Stranges S, Rayman MP, Winther KH, Guallar E, Cold S, Pastor-Barriuso $R$. Effect of selenium supplementation on changes in HbAlc: results from a multiple-dose, randomized controlled trial. Diabetes Obes Metab. (2019) 21:541-9. doi: 10.1111/dom.13549

124. Klein EA, Thompson IM Jr., Tangen CM, Crowley JJ, Scott Lucia M, Phyllis J, et al. Vitamin E and the risk of prostate cancer: the Selenium and Vitamin E Cancer Prevention Trial (SELECT). JAMA. (2011) 306:154956. doi: 10.1001/jama.2011.1437 
125. Karalis DT. The beneficiary role of selenium in type II diabetes: a longitudinal study. Cureus. (2019) 11:e6443. doi: 10.7759/cureu s.6443

126. Institute of Medicine (US) Panel on Dietary Antioxidants and Related Compounds. Dietary Reference Intakes for Vitamin C, Vitamin E, Selenium, and Carotenoids. Washington, DC: National Academies Press (US). 7, Selenium (2000). Available online at: https://www.ncbi.nlm.nih.gov/books/ NBK225470/

127. Allingstrup M, Afshari A. Selenium supplementation for critically ill adults. Cochrane Emergency and Critical Care Group. Cochrane Database Syst Rev. (2015) 2015:CD003703. doi: 10.1002/14651858.CD0037 03.pub3

128. Calder PC, Carr AC, Gombart AF, Eggersdorfer M. Optimal nutritional status for a well-functioning immune system is an important factor to protect against viral infections. Nutrients. (2020) 12:1181. doi: 10.3390/nu120 41181
129. Jayawardena R, Sooriyaarachchi $\mathrm{P}$, Chourdakis $\mathrm{M}$, Jeewandara $\mathrm{C}$, Ranasinghe P. Enhancing immunity in viral infections, with special emphasis on COVID-19: a review. Diabetes Metab Syndr. (2020) 14:367-82. doi: 10.1016/j.dsx.2020.04.015

Conflict of Interest: The authors declare that the research was conducted in the absence of any commercial or financial relationships that could be construed as a potential conflict of interest.

Copyright (C) 2020 Hiffler and Rakotoambinina. This is an open-access article distributed under the terms of the Creative Commons Attribution License (CC BY). The use, distribution or reproduction in other forums is permitted, provided the original author(s) and the copyright owner(s) are credited and that the original publication in this journal is cited, in accordance with accepted academic practice. No use, distribution or reproduction is permitted which does not comply with these terms. 